UDK 582.475:502.131.1(497.6)

\title{
ASSESSING THE COSTS AND BENEFITS TO CONSERVE THE ENDEMIC SPECIES Picea omorica (Pančić) Purk. IN BOSNIA AND HERZEGOVINA
}

\section{Procjena troškova i koristi konzervacije endemske vrste Picea omorica (Pančić) Purk. u Bosni i Hercegovini}

\author{
Florin Ioras ${ }^{1}$, Mirza Dautbasić ${ }^{2}$, Ioan Vasile Abrudan ${ }^{3}$, Dalibor Ballian ${ }^{2}$, \\ Osman Mujezinović ${ }^{2}$, Jegatheswaran Ratnasingam ${ }^{4}$,
}

\begin{abstract}
Adoption and implementation of sustainable biodiversity conservation policy is essential for sustaining natural resources. But development of effective strategies to achieve them is problematic. This is often the case due to the limited knowledge about the impact of biodiversity conservation policies on livelihood of local people. This study uses dichotomous choice format to assess cost and willingness to engage in the conservation of an endemic species - Picea omorica (Pančić) Purk.in Bosnia Herzegovina. The empirical data was generated from sites in the vicinity of Srebrenica, north east Bosnia and Herzegovina. The data was analyzed with the aid of the logit regression model. The study showed that the respondents' mean willingness to pay per year to conserve the pine was 1.4 percent of their income from non-timber forest products. The decision to conserve Picea omorica was influenced by factors such as cost associated with conservation, income from non-timber forest products, the distance of the respondent's residence to the site location, education and occupation.
\end{abstract}

Key words: Picea omorica, Bosnia and Herzegovina, Srebrenica, High Conservation Value Forest, WTP, CV

\section{INTRODUCTION - Uvod}

More than 60 percent of the surface of Bosnia and Herzegovina $(\mathrm{BiH})$ is covered by forest (LOJO ET AL., 2011), and in some areas (the Herzegovina region) the share is over 90 percent. BiH covers three globally significant ecosystems identified by WWF's Global 2000 programme: the European - Mediterranean Montane Mixed

\footnotetext{
${ }^{1}$ Buckinghamshire New University

${ }^{2}$ Faculty of Forestry, University of Sarajevo

${ }^{3}$ Faculty of Silviculture and Forest Engineering, Transylvania University

${ }^{4}$ Faculty of Forestry, University Putra Malaysia
} 
Forests; Mediterranean Forests, Woodlands and Scrubs; and Balkan Rivers and Streams. BiH hosts globally important sites identified under different programmes: Ramsar sites (e.g. Hutovo Blato which is also an important bird area); relatively undisturbed virgin forests like Perucica (a UNESCO site), and the forest preserves of Janj and Lom (MAUNAGA ET AL., 2001). Its rich biodiversity includes over 5,000 confirmed taxa of vascular flora, 450 of which are only endemic to BiH (REDžlć 2011). BiH's forest resources are among the richest in Europe, with a wide variety of coniferous (ŠILIĆ, 2005) and deciduous species in largely intact and undisturbed ecosystems (VIŠNJIĆ ET AL., 2009). A number of endemic species important for European biodiversity (such as Picea omorica (Pančić) Purk., or fauna such as Felis silvestris Schreber) are found in $\mathrm{BiH}$ forests and are not protected (?) despite their presence in the IUCN Red List of endangered species or their mention in the European Biodiversity Act. Bosnia and Herzegovina has 3,125 ha (0.1\%) strictly protected (PARVIAINEN ET AL., 2000) of its 3,231,500 ha of forest (LOJO ET AL., 2011).

Picea omorica (Pančić) Purk. (Po) is an endemic species located in $\mathrm{BiH}$ along the river Drina (JOVANOVIĆ, 1985). This species has a total range of only 250 ha, and it is located between 800-1,600 m altitude (BALLIAN ET AL., 2006). Srebrenica is situated in the north east part of $\mathrm{BiH}$ and it represents the most northern location of Po with a total stand cover of about 52 ha (BALLIAN ET AL., 2006). Forests around Srebrenica are important for the local communities as a source of non-timber products and mineral water. Some 3,500 forest stands have already been classified as High Conservation Value Forest (HCVF) (IORAS ET AL., 2009; IORAS AND DAUTBASIC 2008). Such forests are of outstanding and critical importance due to their environmental, socio-economic, cultural, biodiversity and landscape value. In most developing countries non-timber forest products such as game meat, mushrooms, berries and medicinal plants contribute to livelihood of people who reside in rural areas (OSEMEOBO AND UJOR, 1999). In Srebrenica region, income from raspberries picking and processing help to sustain people livelihood due to the high unemployment met in this region. Therefore conservation regulations of some parts of the forest will have negative implications on income of these people as a result of specific access restrictions. In order to minimise the risk, there has to be a balance between use of this resource and its conservation (AVDIBEGOVIC ET AL, 2010). In this way the conservation of endemic species such as Po will contribute to the food security of the people, as well as perform vital environmental functions. This will give the rural poor the opportunity to have access to sustainable livelihood.

The value of Po is a reflection of its meaning to the society where it is found, its value today arises from the future value. If individual's perceptions of future value of the Po is high, it will most likely be conserved, i.e. the individual's option value for the plant is positive, suggesting that s/he would be willing to conserve the pine for its use in the future. The economic value for the conservation of the Po cannot be observed in the market. This can be estimated using non-market valuation methods such as contingent valuation (BOYLE AND BISHOP, 1987; CARSON, 2004; RUBIN ET AL., 1991; GarRod AND Willis, 1999; Champ et AL., 2003; CARSON ET AL., 1996). The 
contingent valuation method is a survey-based economic technique which typically asks how many people would be willing to pay or willing to accept compensation to maintain the existence of environmental feature e.g. biodiversity. Individuals may be willing to pay for non-use environmental benefits. However, these benefits are likely to be implicitly treated as zero unless their monetary value is estimated. Since people do not reveal their willingness to pay for non-use environmental benefits (e.g. biodiversity conservation) through their purchases, the option for estimating this value may be by asking them how much they would be willing to pay.

The permanent loss of forest around the world is a cause of global concern. Various initiatives have been undertaken at national and international level to reduce deforestation of the forest around the world. One of these initiatives is the establishment of protected areas. More than 19.6 million square kilometre (11.5\%) of the land surface of the Earth are protected (WorLD DATABASE ON PROTECTED AREAS, 2005). This strategy has been fairly successful in developed countries, but has not been very successful in developing countries (DIXON AND SHERMAN, 1990). Inadequate linkages between local communities and conservation efforts undertaken in the protected areas often risk to achieving the conservation objective (HANLEY ET AL., 2009). The cooperation of the local communities is needed for successful conservation initiatives because activities of the people often have effects on the conservation goals. Therefore, it is important to have knowledge about biodiversity conservation strategies which may be more appropriate for developing countries. This will help policy makers with regards to decisions concerning how to package conservation project to make it more sustainable. It is considered that if individuals have continuous access to non-timber products they may not have the incentive to protect endemic species such as Po. The aim of this study is to estimate the cost borne by the Srebrenica community to conserve the Po and factors influencing their decision to protect this species.

\section{METHODOLOGY - Metod rada}

The study focused on Srebrenica region in the north eastern part of B-H (Figure 1). The Srebrenica forestry district has around 35,000 ha. The main vegetation association is represented by Luzulo-Fagetum beech forests and in small extent by Musci-Fagetum and Fagetum montanum illyricum with oak. Sporadically is also found thermophilic forest stands of fagus (Ostryo-Fagetum), forests of oaks and black hornbeam (Querco-Ostryetum), and hornbeam forests (Orno-Ostryetum) (ANON, 2008). Oak forests are mainly represented by the Quercetum petraeae-cerris, Quercetum confertae-cerris, Quercetum petraeae montanum and Querco-Carpinetum associations. 


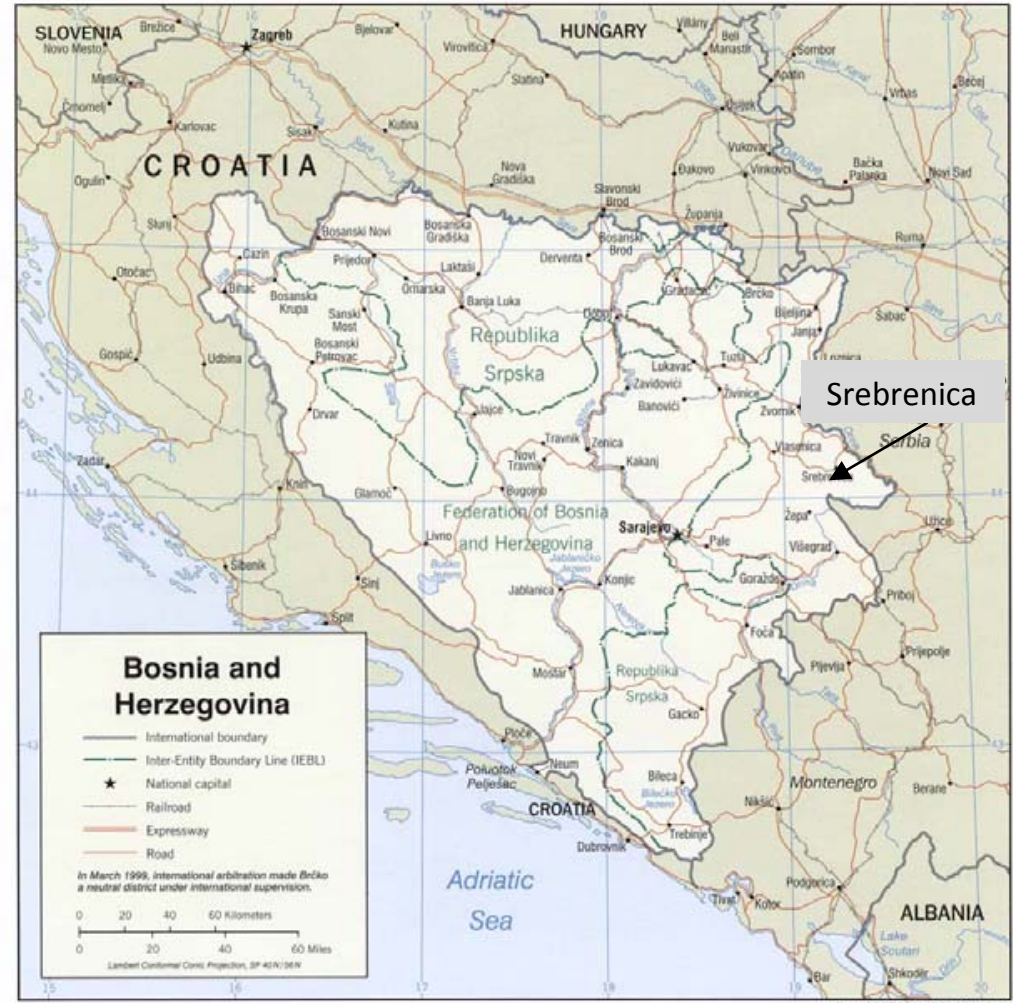

Figure 1. Srebrenica location within Bosnia and Herzegovina

Slika 1. Položaj Srebrenica na karti Bosne i Hercegovine

Eighty one villages are part of the Srebrenica municipality. The municipality has a total population of 8,000 people (IORAS ET AL, 2008). These people mainly depend on wood processing industry, farming and gathering of non-timber forest products activities for livelihood. The main non-timber forest product is represented by raspberries and wild mushrooms. Also the forest harbours valuable mineral water springs that could be a valuable source of income if SPA is to be established (IORAS ET AL., 2008).

As a result of HCVF for some parts of the forest, there are discussions for this forest to become part of a corridor that links 3 international National Parks: Sutjeska (Bosnia Herzegovina), Durmitor (Montenegro) and Tara (Serbia).

The data collection involved standardized personal interviews that were designed, and tested on a pilot group outside the study area. Pre-test interviews were conducted in August 2008 covering 20 randomly selected individuals. Findings from the pre-test interviews determined several changes in the questionnaire such as the wording of the hypothetical market scenario. The major interview was conducted during the months April and May 2009. Two villages from the 19 villages located at the periphery of forest were randomly selected for the survey. The two villages were 
Luka and Radosevici (Figure 2). These villages are located in close proximity to the Po stands and are more likely to be affected by any future conservation initiatives. Every other house along the main street was visited in each of the villages. If a house was not occupied, then it was omitted and the next house was visited. The interviewees alternated between the eldest male and the eldest female in each selected household. If the gender of the eldest in a household did not coincide with the interviewee selection method, then a member of the opposite gender was interviewed and the respondent's gender was alternated again from there on. A total of 150 respondents were interviewed in the study area ( 75 respondents in each village).

The aim of the study was described to the respondents and they were asked about their household size and occupation. Furthermore, they were asked about their education and income from non-timber forest products. Respondents were asked about the distance of their residence to the forest.

The hypothetical market scenario was developed to describe the conservation of the Po in order to increase its covered area. The population sample was made aware that conservation of Po will be beneficial for sustaining the opportunity to have access to income from NTFPs. Before this study it was doubtful whether the payment vehicle - set-aside $2 \%$ of your income to conserve a tree species - will be applicable to the study area. The policy on conservation of Po needs evaluation of the considered payment vehicle to find out if it is the right choice. It is the tradition of the people to bargain the price of many things they buy, but they are not used to "take-it-or-leaveit" kind of purchase which is common in the developed countries.

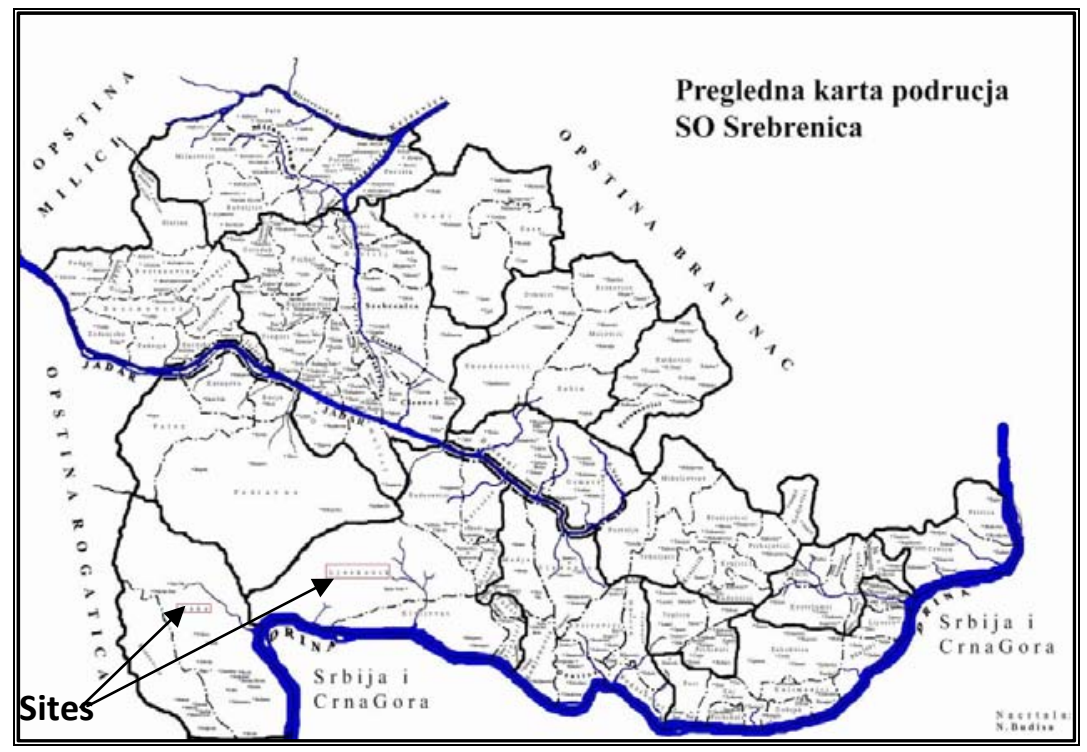

Figure 2. Luka and Radosevici villages location

Slika 2. Lokacija sela Luka i Radoševići 
The respondents were randomly assigned to eight groups corresponding to, i.e. $6.0,12.0,18.0,24.0,30.0,36.0$, and 42.0 Convertible Marks (CM), respectively. One $\mathrm{CM}$ is $0.5 €$. After describing the hypothetical market scenario and payment vehicle, the respondents were asked to provide a „yes” or „no" response whether they would be willing to conserve the Po if it will cost them the amount assigned to them per year.

Individual's decision to conserve it will also depend on whether the benefit from conservation will outweigh that from alternative arrangement, i.e. not to conserve Po (DAUTBASIC ET AL, 2010). If we assume that an individual chooses the most attractive alternative from the two options, i.e. to conserve or otherwise, then the observation of the choices will reveal the individual's preference. If the individual i choose to conserve Po this implies that:

$$
U_{i 1}>U_{i 0}, \quad 0 \neq 1
$$

where $U_{i 1}$ and $U_{i 0}$ are the utilities that the individual $i$ associates with; conserve Po and otherwise, respectively. The utility $U_{i j}$ that the alternatives $j(j=1$ : conserve Po; $j$ $=0$, otherwise) gives individual $\mathrm{i}$ is composed of two parts; a systematic term, which depends on an attributes vector $X$ (cost associated with conservation, income from non-timber forest products, education, occupation etc) and another random one $\varepsilon_{\mathrm{ij}}$ :

$$
U_{i j}=U_{1 \mathrm{j}}-U_{0 j} \beta_{\mathrm{j}}+\varepsilon_{\mathrm{ij}}
$$

It follows that the willingness to pay to conserve $\mathrm{Po}, \mathrm{CPo}_{\mathrm{i}}$, can be modelled as a latent variable, which is a linear function of a vector of attributes which characterize the $i$-th individual as:

$$
\mathrm{CPo}_{\mathrm{i}}=X_{\mathrm{i}} \beta+\varepsilon_{\mathrm{i}}
$$

where $X_{i}$ is the personal characteristics of the individual i, $\beta$ represents parameters to be estimated and $\varepsilon_{\mathrm{i}}$ the disturbance term. The disturbance term is assumed to be independently and identically distributed since $\mathrm{CPo}_{i}$ is latent, i.e. not observable. Let $\mathrm{I}_{\mathrm{i}}$ be the indicator variable, so that:

$$
\begin{aligned}
& \mathrm{I}=1, \text { if } \mathrm{CPo}=\text { no, } \\
& =0, \text { otherwise }
\end{aligned}
$$

This means $\mathrm{CPo}>\mathrm{X}_{1}$ (payment offered to a respondent) when $\mathrm{CPo}=$ yes.

In this study, we can distinguish between two arrangements namely, conserve Po or otherwise. Given the binomial nature of such institutional arrangements, and assuming that an individual can identify the preferred arrangement, a binomial logit econometric technique (GREENE, 2003) can be used in the empirical investigation of the factors associated with the decision of the individual. The probability that the individual i will choose to conserve Po can be expressed as binomial logit model: 


$$
\operatorname{Prob}[\mathrm{yes}]=\frac{e^{x_{i \beta}}}{1+e^{x_{i \beta}}}
$$

Equation (5) can be expressed as:

$$
\log [\operatorname{Prob}(\text { yes }) / 1-\operatorname{Pr} o b(\text { yes })]=\beta_{0}+\beta_{1} \mathrm{X}_{1 \mathrm{i}}+\ldots+\beta_{\mathrm{n}} \mathrm{X}_{\mathrm{n}}+\varepsilon_{\mathrm{i}}
$$

where, $\operatorname{Prob}(y e s)$ is the probability of the $\mathrm{CPo}_{i}$ occurring, $\beta_{0}$ is the intercept, $\beta_{1}$ is the coefficient associated with the cost of conserving Po $X_{1}$, and $\beta_{n}$ a vector of regression coefficients associated with other personal characteristics of the individual $\mathrm{X}_{\mathrm{n}}$ and $\varepsilon_{\mathrm{i}}$ is the error term which is logistically distributed. The logit model was estimated using the LIMDEP NLOGIT version 4.0.1 statistical package (Table 2). The effect of respondents'characteristics on CPoi was examined using the logit model. Mean willingness to pay to conserve Po (MCPo) was estimated as defined by HANEMANN (1989) to be:

$$
1 / \mathrm{B}_{1} *\left(\left(\ln \left(1+\exp \left(\mathrm{B}_{0} \quad+\Sigma\left(\mathrm{B}_{\mathrm{n}}\left(\mathrm{Z}_{\mathrm{n}}\right)\right)\right)\right)\right)\right.
$$

where $Z_{n}$ are the sample means of the independent variable.

Equation 6 allows negative WTP values for an individual whereas eq 7 treats WTP as a nonnegative random variable (and is consistent if the payment in eq 6 is in logarithm) (HANEMANN, 1989). Therefore, equation 7 does not allow that some respondent's WTP would be negative (indicating that the person feels conservation harmful). This means that - by assumption - all respondents are benefiting from the conservation of Po.

The following explanatory variables had been considered as having an impact on the willingness to pay to conserve Po (CPo):

- Cost associated with conservation of Po (COST). Individuals often aim at cost minimisation during their decision to purchase goods and services (HANLEY ET AL., 2007).

- Income from non-timber forest products (NT). Individuals often support projects which they expect to derive benefit. Conservation of the Po will sustain the availability of the tree species. This will give individuals who derive benefit from non-timber forest products the opportunity to have access to sustainable income.

- The distance of the respondent's residence to the forest (D). Individuals who live closer to the forest may lose access to the forest if a strict conservation regime is employed. These individuals may not be willing to give up their rights for conservation.

- Respondent's education (E). Formal education often gives individuals the opportunity to comprehend the importance of biodiversity conservation.

- Occupation (O). Individuals who engage in traditional employment such as wood processing, farming and gathering of non-timber forest products 
often depend on natural resource for livelihood. Conservation of the Po may reduce their income from non-timber products and hence they may be less willing to conserve the pine.

- Gender (G). In BiH women often engage in the collection of non-timber forest products. Conservation of the forest resources will sustain their availability and may give the women opportunity to have sustainable income.

- Household size (HH). In most developing countries individuals who have less formal education and engage in traditional employment often have larger family size. Conservation of Po could potentially lower their livelihood as a result of reduced access to the product.

The results of the impacts of the above variables on respondents' CPo are presented in Table 2 .

\section{RESULTS AND DISCUSSION - Rezultati i diskusija}

\section{The sample and estimate of cost for conserving Po}

Sixty-one percent of the respondents were willing to conserve the Po. Of these respondents $33 \%$ were female and $28 \%$ male. Thirty - nine percent of the respondents were not willing to conserve, this comprised $13 \%$ female and $28 \%$ male. This shows that the female respondents were more willing to conservation. The possible reason may be that in the study area most women often engage in gathering of non-timber forest products for livelihood. Descriptive statistics for the respondents' characteristics are presented in Table 1.

Table 1 Descriptive statistics for socio-economic characteristics

Tabela 1. Deskrtptivna statistika socio-ekonomskih pokazatelja

\begin{tabular}{|l|r|r|}
\hline \multicolumn{1}{|c|}{ Variable } & \multicolumn{1}{c|}{ Mean } & \multicolumn{1}{c|}{ Std. Dev. } \\
\hline NT Income $(€)$ & 350 & 396 \\
\hline Distance & 5.457 & 4.534 \\
\hline Education & 0.820 & 0.385 \\
\hline Occupation & 0.533 & 0.500 \\
\hline Gender & 0.533 & 0.499 \\
\hline HH size & 8.660 & 4.942 \\
\hline
\end{tabular}

Seventy-two percent of the respondents have higher and secondary education and $63 \%$ engaged in traditional employment such as timber processing, farming and gathering of non-timber forest products activity. Fifty-five percent of the respondents were male and average household size was 4 persons.

The MCPo of the respondents was $338 \mathrm{KM}(€ 169)$ per year (aided by equation 7). This has a value of $299 \mathrm{KM}(€ 149.5)$ following an adjustment derived from equation 6 . This was 1.4 percent of the respondents' mean annual income from 
non-timber forest products. Adult individuals ( $\geq 20$ years) is estimated to be $65 \%$ of the total population in the Srebrenica region. Since the total population in the Srebrenica region is 8,000, the adult population there should be 5,200. Aggregating the MCPo over the relevant population of 5,200, the total perceived cost for the conservation of the Po to residents at the periphery of the forest is estimated to be $1,554,800 \mathrm{KM}(€ 777,400)$ each year. Such amount however will be impossible to request from local people as contribution for the benefit of conserving Picea omorica. This has more an indicative value for people willingness to do something for conservation when right payment vehicle are in place.

\section{Influence of respondents' characteristics on willingness to conserve Po}

The study examines willingness to conserve the Po across all groups of the respondents, and factors which might have influenced the CPo responses. This analysis is shown in Table 2, which is based on binary logitmodel estimates. The dependent variable was respondents' 'yes' or 'no' responses to the CPo.

Table 2 Estimated binary logit model results for willingness to conserve Picea omorica (Pančić) Purk. Tabela 2. Rezultati procjenjenog binarnog logit modela za spremnost za konzervaciju Picea omorica (Pančić) Purk.

\begin{tabular}{|c|r|r|c|}
\hline Variable & Coefficient & Std. error & \multicolumn{1}{c|}{ t-ratio } \\
\hline Constant & -1.501 & 1.845 & -0.814 \\
\hline Cost & -0.00505 & 0.001 & $-3.580^{* * *}$ \\
\hline NT & 0.001 & 0.0005 & $2.376^{* *}$ \\
\hline D & 1.004 & 0.312 & $3.218^{* * *}$ \\
\hline E & 0.387 & 0.135 & $2.860^{* * *}$ \\
\hline O & -3.916 & 1.559 & $-2.511^{* *}$ \\
\hline G & -0.209 & 1.086 & -0.192 \\
\hline H & -0.108 & 0.116 & -0.932 \\
\hline
\end{tabular}

http://en.wikipedia.org/w/index.php?title=Emanuel_von_Purkyne\&action=edit\&redlink=1

$\begin{array}{ll}\text { McFadden Pseudo R } & 0.842 \\ \text { Chi-square } & 154.711 \\ \text { Log likelihood } & -14.513 \\ \text { Restricted log likelihood }-91.868 & \\ \text { \% correctly predicted } & 97.08 \% \\ \text { No of observations } & 150 \\ { }^{* *} \text { significant at } 1 \% & \\ { }^{* * *} \text { significant at 5\% } & \end{array}$

The coefficient associated with the cost of conservation of Po had a negative and statistically significant impact on the CPo, i.e. the greater the cost the less the willingness to conserve it. A possible reason may be that an increase in the 
cost of conservation may lower benefit which the respondents derive from nontimber products processing business.

The coefficient associated with the respondents' income from non-timber forest products has positive and statistically significant effect on the CPo. This suggests that an increase in the respondents' income from non-timber forest products increases the CPo. The possible reason may be that the more benefit an individual derives from a good the more will he/she be willing to preserve it.

Distance between the respondent's residence and the Srebrenica forest had a positive and statistically significant impact on the CPo, i.e. the farther the respondent's residence is from the park the more the CPo is. A possible reason may be that respondents who live farther from the forest might not have experienced a reduction in access to the forest. Hence, conservation of Po may not result in a greater reduction in their livelihood compared with respondents who reside closer the forest who may witness reduction in access to non-timber products.

The coefficient associated with the respondents' education had a positive and statistically significant effect on the CPo, i.e. respondents who have formal education were more willing to conserve Po. A reason may be that respondents who have formal education often have the ability to infer about future benefit of conservation projects.

Respondents' occupation had a negative and statistically significant impact on the CPo. This suggests that respondents who engage in non-traditional employment such as teaching and nursing were more willing to conserve Po. A possible reason may be that respondents who are occupied with non-traditional employment may not be affected with a reduction in livelihood as a result of the conservation of some forest sites.

Coefficients associated with the respondents' gender and household size were not statistically significant.

\section{CONCLUSION - Zaključci}

The economic valuation of decision to conserve a natural resource is important in the study of individual consumer behaviour. It indicates the opinion of individual consumers about certain natural resource management objectives and identifies individual consumer motivations with respect to willingness to conserve the resource. This study has focussed on the benefit and willingness to contribute to conserve Piceao morica (Pančić) Purk. This study showed that about sixty percent of the respondents were willing to conserve the pine and the cost associated with the conservation of it that local people were willing to cover was 1.4 percent of the respondents' annual income from non-timber forest products. Conservation of the pine is perceived to contribute to sustainable development of the region and to be of benefit to all categories of the individuals in the community. The study showed that individuals (respondents) who have more income from non-timber forest products, live farther from the forest, have secondary or higher education and engage in non- 
traditional employment will benefit more from conservation of the Po. The dichotomous choice format used in this study is new to the people in the study area, however it shows that it can be successfully applied in other parts of the country.

This study provides certain policy insights. For example, individuals who live in the vicinity of Srebrenica's forest may bear some costs as a result of any future conservation initiatives. Furthermore, because of the economic burden the conservation may place on them, individuals may be less willing to embrace biodiversity conservation projects unless a payment vehicle for compensation is in place. Thus, the costs borne by individuals may have important implications for the implementation of conservation policies. Further work is needed in the area of incentives which may engender individuals to accept conservation initiatives.

\section{REFERENCES - Literatura}

ANONimus, (2008): Forest management plans for Srebrenica Municipality for period: 1 January 2008 to 31 December 2017.

Avdibegovic M., Nonic D., Posavec S., Petrovic N., Maric B., Milijic V., Krajter S., IORAS F., ABRUdAn I.V. (2010): Policy Options for Private Forest Owners in Western Balkans: A Qualitative Study. Notulae Botanicae Horti Agrobotanici, Vol 38, No 1: 257-261.

Ballian, D., Longauer, R., Mikić T., PaUle, L., KajBA, D.,.GömÖry, D. (2006): Genetic structure of a rare European conifer, Serbian spruce (Picea omorika (Panč.) Purk.). Plant Systematics and Evolution, Springer-Verlag 260: 53-63.

BOYLE, K., BISHOP, R. (1987): Valuing wildlife in benefit-cost analyses: a case study involving endangered species. Water Resources, 23: 943-950.

CARSON, R. (2004): Contingent valuation: A comprehensive bibliography and history. Cheltenham, UK and Northampton, MA: Edward Elgar.

Carson, R., Flores, N., MARtin, K., AND WRIGHT, J. (1996): Contingent valuation and revealed preference methodologies: comparing the estimates for quasi-public goods. Land Economics, 72: 80-99.

Champ, P. A., Boyle, K., AND Brown, T. C., (EDS.), (2003): A primer on non-market valuation. Boston: Kluwer Academic publishers.

Dautbasic M, Ioras, F., Abrudan, IV, Ratnasingam, J. (2010): Funding Biodiversity Protection in Central and Eastern Europe - A Case Study of Bosnia Herzegovina. Notulae Botanicae Horti Agrobotanici, Vol 38, No 1: 252-256

Dixon, J. A., Sherman, P. B. (1990): Economics of protected areas: A new look at benefits and costs. Earthscan, London, UK.

GARROD, G., WILLIS, K. G. (1999): Economic valuation of the environment.Edward Elgar, Cheltenham, UK. 
Greene, W. (2003): Econometric Analysis. New Jersey: Prentice Hall.

Hanley, N., Shogren, J. F., AND White, B. (2007): Environmental Economics in theory and practice. Palgrave Mac Millan, New York.

HANEMANN, M. (1989): Welfare evaluations in contingent valuation experiments with discrete response data: Reply', American Journal of Agricultural Economics 71(4), 1057-1061.

Ioras, F., Abrudan, I.V., Dautbasic, M., Avdibegovic, M., Gurean D., Ratnasingam, J. (2009): Conservation gains through HCVF assessments in BosniaHerzegovina and Romania. Journal of Biodiversity and Conservation 18: 33953406.

IORAS F, DAUTBASIC M. (2008): The Impact of Establishing High Conservation Value Forest (HCVF) on Forest Policy in Bosnia and Herzegovina, Proceedings of the 10th International Symposium on Legal Aspects of European Sustainable Development May 7-9, 2008. Sarajevo.

Jovanovic, B. (1985): Dendrologija. Sumarski fakultet Beograd.

LOJo, A., BALIć,B. (2011): Prikaz površina šuma i šumskih zemljišta. In: LoJo, A., Balić, B., HočeVar, M., Vojniković, S. VIŠnJIĆ, Ć., Musić, J., Delić, S., TReštić, T., Čabaravdić, A., Gurda, S., Ibrahimspahić A., Dautbašıć, M., Mujezinović, O.: Stanje šuma i šumskih zemljišta u Bosni i Hercegovini nakon provedene druge inventure šuma na velikim površinama u periodu 2006. do 2009. godine. (u tisku).

Maunaga, Z.; Govedar, Z.; Burlica, Č.; Stanivuković, Z.; Brulić, J., LazareV, V., MATARUGA, M. (2001): Plan gazdovanja za šume sa posebnom namjenom u strogim rezervatima prirode Janj i Lom. Studija šumarskog fakulteta u Banja Luci.

Parviainen J., Bücking W., VAndeKerkHove K., Schuck A. ANd PäIVINEN R, (2000): Strict forest reserves in Europe: efforts to enhance biodiversity and research on forests left for free development in Europe (EU-COST-Action E4). Forestry 73 (2):107-118.

REDŽIĆ, S. (2011): Drugi međunarodni kolokvij „BIODIVERZITET - TEORIJSKI I PRAKTIČNI ASPEKTI“, posebna izdanja ANUBIH, CXIVIII, Odjeljenje prirodnih i matematičkih nauka, Zbornik radova22:47-70.

RuBin, J., HELFAND, G., AND LOOMIS, J. (1991): A benefit-cost analysis of the northern spotted owl. Journal of Forestry, 89(12): 25-30.

ŠıLIĆ Č. (2005): Atlas dendroflore (drveće i grmlje) Bosne i Hercegovine, Matica Hrvatska, Čitluk - Franjevačka kuća Masna Luka.

World Database on Protected Areas, (2005): 2005 World Database on protected areas, CD, IUCN and UNEP.

VisnuIC, Ć., VouniKovic, S., IORAS,F., DaUtbasic, M., ABRUdan, I.V., GuREan, D.M., Lojo, A., Trestic, T., Ballian, D., BaJRIC, M. (2009): Virgin Status Assessment 
of Plješevica Forest in Bosnia - Herzegovina.Notulae Botanicae Horti Agrobotanici Cluj-Napoca, Vol 37, No 2, pp. 22-27.

\section{SAŽETAK}

Usvajanje i sprovođenje politike očuvanja biodiverziteta je od suštinskog značaja za održavanje prirodnih resursa. Međutim, razvoje fikasne strategije za postizanje ovog cilja je problematičan, a najčešće zbog ograničenih znanja o uticaju politike očuvanja biološke raznolikosti na život lokalnog stanovništva. U cilju utvrđivanja raspoloženja i utrđivanje iznosa novčanih sredstava za zaštitu endemske vrste, pančićeve omorike (Picea omorica) u Bosni i Hercegovini korišten je metod dihotome varijable. Istraživanja su obavljena na širem području Srebrenice u sjeveroistočnoj Bosni. Dobijeni podaci su analizirani korištenjem "logitregresionog modela". Istraživanja pokazuju da su, u cilju zaštite pančićeve omorike, ispitanici spremni da izdvoje 1,4\% od dobiti koju ostvare prodajom "nedrvnih šumskih proizvoda". Na odluku o zaštiti pančićeve omorike, prema ispitanicima, najveći uticajimaju sljedeći faktori: troškovi vezani za zaštitu vrste, prihodi od prodaje nedrvnih šumskih proizvoda, udaljenost lokacije koju treba zaštititi, obrazovna struktura i zanimanje ispitanika. 